\title{
Potential use of the Eucalyptus globulus vacuolar pyrophosphatase 1 (EgEVP1) to generate drought and salt resistant plants
}

\author{
Erwin Krauskopf ${ }^{*}$, Maria Cecilia Gamboa² \\ From IUFRO Tree Biotechnology Conference 2011: From Genomes to Integration and Delivery \\ Arraial d'Ajuda, Bahia, Brazil. 26 June - 2 July 2011
}

Desertification is a phenomenon that affects vast territories worldwide usually caused by high soil salt concentrations, being salt and water stress one of the main problems that affect plant growth. Part of the strategy developed by the plant to face these stresses consists on the compartmentalization of cytoplasmic $\mathrm{Na}^{+}$within the vacuole, by a coordinated expression of a $\mathrm{H}^{+}$pump that uses pyrophosphate as a source of energy (known as vacuolar pyrophosphatase) and a $\mathrm{Na}^{+} / \mathrm{H}^{+}$exchanger, both located on the vacuole membrane. The vacuolar pyrophosphatase has been described in various plant species, much of which are of commercial importance, such as rice, wheat and corn, along some woody species such as poplar and apple. In our laboratory we isolated the cDNA of the Eucalyptus globulus vacuolar pyrophosphatase (EVP1), establishing by real-time PCR that its transcript expression increases when Eucalyptus globulus plants are subjected to water and salt stress. An analysis of its genomic sequence allowed us to identify four introns and a promoter region of approximately $2 \mathrm{~Kb}$. The fusion of the GUS reporter gene to the promoter region as well as to the first EVP1 intron allowed us to establish for the latter a possible regulatory function, in addition to identifying the promoter tissue-specific expression in A.thaliana plants. Finally, A. thaliana transgenic plants generated by overexpressing EVP1 produced seeds that exhibited a higher germination rate in high salt conditions compared to the wild-type plants. Furthermore, adult transgenic plants had more leaves in the rosette and a higher tolerance to salt and water stress.

Funded by: PFB-016 and DI-UNAB

\footnotetext{
* Correspondence: ekrauskopf@unab.cl

${ }^{1}$ Facultad de Ciencias Biologicas, Universidad Andres Bello, Santiago, Chile Full list of author information is available at the end of the article
}

\section{Author details}

${ }^{1}$ Facultad de Ciencias Biologicas, Universidad Andres Bello, Santiago, Chile.

${ }^{2}$ Fundacion Ciencia para la Vida, Santiago, Chile.

Published: 13 September 2011

doi:10.1186/1753-6561-5-S7-034

Cite this article as: Krauskopf and Gamboa: Potential use of the

Eucalyptus globulus vacuolar pyrophosphatase 1 (EgEVP1) to generate drought and salt resistant plants. BMC Proceedings 2011 5(Suppl 7):O34.

Submit your next manuscript to BioMed Central and take full advantage of:

- Convenient online submission

- Thorough peer review

- No space constraints or color figure charges

- Immediate publication on acceptance

- Inclusion in PubMed, CAS, Scopus and Google Scholar

- Research which is freely available for redistribution 